\title{
Maturity models to evaluate lean construction in Brazilian projects
}

\author{
Priscila Mirapalhete Rodegheri ${ }^{1}$ (D), Sheyla Mara Baptista Serra ${ }^{1}$ (D) \\ ${ }^{1}$ Federal University of São Carlos - UFSCar, São Carlos, SP, Brazil.
}

How to cite: Rodegheri, P.M. and Serra, S.M.B. (2020), "Maturity models to evaluate lean construction in Brazilian projects", Brazilian Journal of Operations \& Production Management, Vol. 17, No. 2, e2020852.

https://doi.org/10.14488/BJOPM.2020.016

\begin{abstract}
Goal: This research aim is to answer the question: which Maturity Model (MM) is suitable to evaluate LC implantation in Brazilian Small-Medium Sized Enterprises (SME) of construction.

Design / Methodology / Approach: A literature review was carried out to identify MM related to LC. Then, a case study was conducted applying selected MM in one SME located in São Paulo country town state. The data collection was carried out from April to August of 2018 with professionals of the construction company. A content analysis was used to lead the suited MM through the case study outcomes.

Results: The case study results were analyzed and guide to the suitable MM for this scenario. Improvements to the MM and complementary tools for companies starting on LC implementation are discussed. It was verified that the elected MM has many advantages and can be used in different Brazilian SME of construction.

Limitations of the investigation: The MM assessment cover just one project and the content analysis classification criteria embrace this project issues and the experience provide by this application.

Practical implications: This paper point out the suitable MM to be used by construction practitioners in Brazilian construction projects that are starting lean implementation an SME seeking to meet the gap of elect one model to fill this goal and spread lean philosophy in this scenario.

Originality / Value: This paper contributes to the LC body of knowledge discussing the individuality of Brazilian SME construction projects and the challenge of choosing the MM that fit these companies, leading to method selection criteria that support this issue.
\end{abstract}

Keywords: Lean Construction; Maturity Models; Performance Measurement Systems; Civil Construction; Construction Management.

\section{INTRODUCTION}

From the beginning of civilizations, the development of science and technology became necessary to improve the human condition. Civil engineering has become fundamental to communities' organization and has evolved. Construction technological adventures have become frequent and widespread over the years. The evolution had been in the scope of materials, projects, methodologies, tools, and management. Currently, the economic scenario requires efficient and competitive companies. Invest in technology and management models that make proses more efficient and reduce waste is essential, even in terms of cost (Böes et al., 2018).

Lean Construction (LC) stands out for bringing changes in the social, economic and environmental spheres (Gontijo et al., 2018), based on Lean Thinking (LT) developed in the

Financial support: This study was financed in part by the Coordenação de Aperfeiçoamento de Pessoal de Nível Superior - Brasil (CAPES) - Finance Code 001. Conflict of interest: The authors have no conflict of interest to declare.

Corresponding author: priscilamr@ufscar.br, sheylabs@ufscar.br

Received: 10 May 2019.

Approved: 17 Jan 2020

Editor: Osvaldo L. G. Quelhas.

(c) (i) This is an Open Access article distributed under the terms of the Creative Commons Attribution License, which permits unrestricted use,

c) distribution, and reproduction in any medium, provided the original work is properly cited. 
automotive industry. Since the presentation of this philosophy by Koskela (1992), LC was spread worldwide, used and improved among construction professionals. LC is linked by managers as practices that can give superior performance, provide gain and sustain competitive advantage to the company through reducing cost, inventory, and assets required, improving and optimizing internal operational procedures among different functional areas (Zhou, 2016).

Construction management and improvement models, as well as other industries, need systems, methods, and tools to help its implementation, development, and evaluation. From the application of a new management methodology is necessary to measure the adhesion and performance before the implemented modifications, for that are used Performance Measurers Systems (PMS). PMS are support tools to ensure goals through manage performance, human resources and company strategy (Yu et al., 2007). They evaluate a range of factors that should not be based just on financial factors, but also in internal processes, customers, safety, learning, growth, health, and change.

Chose a suitable framework for performance evaluation is considered very important according to Yu et al. (2007), and it should be used periodically to assess performance level and find the cause-and-effect relationship between the indicator and obtained data to improve performance. The PMS disseminated in construction are usually based on Key Performance Indicators (KPI) and Balanced Scorecards (BSC), linking to strategic management models (Cândido et al., 2016).

After the publication by Koskela (1992) and Womack and Jones (1997) and the dissemination of LT, it was necessary to invest in Maturity Models (MM) development focused on LC. This MM may focus on LC elements evaluation or company broad context. The MM of the first group use to be based on Last Planner System (LPS) (Ballard, 2000), in TransformationFlow-Value (TFV) (Moon et al., 2007) or waste quantification, cycle time and rework (Alarcón et al., 2001).

The MM of the second group were based on semi-qualitative approaches, evaluating LC principles in a flexible way (qualitative) and staggering the current state (quantitative). According to Sarhan and Fox (2013), this approach models has disadvantages since they evaluate a great number of factors, it could be subjective and present distortions in the result if the interviewer does not dominate the method and LC principles. Despite this, these MM appraise company adherence to the lean philosophy, adding some reasons for use performance indicators such as strategic alignment, management support, progressive evaluation and current state diagnosis (Sousa et al., 2017).

Therefore, the objective of this research is evaluating the application of different MM with a holistic view of LC use in the same project to answer the question: which MM is best adapted to evaluate the beginning lean journey of Brazilian medium-sized construction companies. To reach this goal, a case study was conducted applying different MM in the same company and the results were evaluated by content analysis to select the suitable MM in this context.

\section{LITERATURE SURVEY}

LC is a philosophy that has been set out to maximizing value, reduce waste while delivering the project with customer requirements. When appropriately applied, the company gets improvements in quality, work relationship and financial aspects, it should be followed with management development (Sousa et al., 2017). Start LC application in a construction company is start a journey were the capabilities should be progressively introduced by strategies aligned with the enterprise goals (Nesensohn, 2014; Soto Becerra, 2016). It is a management strategy that needs to be evaluated, so the implemented improvements could be verified, and weaknesses get focus. Therefore, is necessary establish the company current state and the objectives for the future, so periodic evaluations should be carried out to verify the progress of this journey and what actions must be taken to follow the path of LC development (Carvalho, 2008; Soto Becerra, 2016; Gomes et al., 2018).

To measure company performance in the LC journey, PMS should be implemented and for this, it should be simple to use and appropriate for the organization context. It is essential to support business strategies, after all: who measure, manage (Sarhan and Fox, 2013). 
For Sousa et al. (2017), PMS is considered systems because integrate the tool of the performance measure, strategic management and answer how to improve actions to get there. In this sense, MM is part of any PMS and is not just a tool or a framework to measure the current performance state (Lorenzon, 2008). The MM outputs guide a set of rules that could be applied, regard the company capability, to the systematic lifecycle approach (Nesensohn, 2014).

According to Nesensohn (2014), MM started with Crosby (1979) that structured and presented one framework, with technological advancements, Capability Maturity Model (CMM) was developed and in 1991 started to be used and get success as the first popularized MM. After that, others MM had been set out like Balanced Scorecard (BSC), Total Quality Management (TQM), Performance Measurement Questionnaire (PMQ) and Strategic Scorecard (Carvalho, 2008).

In recent research, Gomes et al. (2018) show that LC principles are correlated to the main themes of business management, industrialization, modularization, demand forecasting, and sustainable actions. Carvalho and Scheer (2017) affirm that analyzed Brazilian construction companies have low knowledge of LC principles and tools application, a similar situation from India, were the application and local application of this philosophy gets started recently (Sainath et al., 2018). Moreover, seven obstacles for Lean Manufacturing (LM) implementation in Brazilian companies from different niches had been set out recently, they are: difficulties understanding and using LM, operational resistance, cultural differences, slow response to market, lack of top/senior management involvement, lack of middle management support and lack of resources to invest (Pereira et al., 2017). Instead, 90\% do Chilean professionals working with LC and consider the philosophy fundamental for the company growth (Salvatierra et al., 2015). Another experience is one of the Highways England that demands LC implementation for all suppliers, showing growth LC level in his country (Tezel et al., 2017).

Recently Lucena and De Mori (2018) quotes and confirm other authors that stated no extensive application of LC in the Brazilian industry nowadays. This research analyzes six MM through ten parameters distributed in four topics. Carvalho's (2008) method had a great performance about the utility of the results for processes optimization. Pereira's (2012) method was considered the most efficient MM to measure LC use (Lucena and De Mori, 2018).

A literature review was carried out in scientific databases searching for "evaluation lean construction", "lean construction indicator", "performance measurement systems lean construction", "performance indicator lean construction" and "maturity model lean construction". Websites of LC institutes, companies and groups were consulted too. Several MM were found and Chart 1 presents some of this MM. They have different origins that reinforce the dissemination of lean culture and models to measure company adherence and performance to $\mathrm{LC}$, and its challenges and benefits. The choice to present this MM was given by the spread of these models or paper in the academic and practical construction community and being embracing about LC and LT. 
Chart 1. Various Maturity Models

\begin{tabular}{|c|c|c|c|c|c|}
\hline $\begin{array}{l}\text { MODEL AUTHOR } \\
\text { (YEAR) COUNTRY }\end{array}$ & INFLUENCED BY & MAIN EVALUATION FACTORS & APPLICATION METHOD & RESULTS SCALE & $\begin{array}{l}\text { VISUAL RESULTS } \\
\text { PRESENTATION }\end{array}$ \\
\hline $\begin{array}{c}\text { MDCE } \\
\text { Arantes (2010) Brazil }\end{array}$ & $\begin{array}{l}\text { Principles of LC by Koskela } \\
\text { (1992) \& principles of LT by } \\
\text { Womack and Jones (1997) } \\
\text { \& concepts proposed by } \\
\text { Rentes (2009) }\end{array}$ & $\begin{array}{l}1 \text { Reduce the share of non- } \\
\text { value-adding activities } \\
2 \text { Increase output value } \\
\text { through systematic } \\
\text { consideration of customer } \\
\text { requirements } \\
3 \text { Reduce variability } \\
4 \text { Reduce the cycle time } \\
5 \text { Simplify by minimizing the } \\
\text { number of steps and parts } \\
6 \text { Increase output flexibility } \\
7 \text { Increase process } \\
\text { transparency } \\
8 \text { Focus control on the } \\
\text { complete process } \\
9 \text { Build continuous } \\
\text { improvement into the } \\
\text { process } \\
10 \text { Balance flow } \\
\text { improvement with } \\
\text { conversion improvement } \\
11 \text { Benchmark }\end{array}$ & $\begin{array}{l}\text { Questionnaire with } \\
24 \text { questions, completed by } \\
\text { external evaluator through } \\
\text { interviews answers from } \\
\text { agent responsible for } \\
\text { implementing LC } \\
\text { philosophy in the company }\end{array}$ & $\begin{array}{l}\text { It considers whether the } \\
\text { principle is "applied," is in } \\
\text { "development" or "non- } \\
\text { applied" and also if the } \\
\text { company has an interest in } \\
\text { "implementation" and sees } \\
\text { this as an "opportunity" }\end{array}$ & $\begin{array}{l}\text { Visual framework } \\
\text { proposed by Rentes (2009), } \\
\text { presenting the evaluation } \\
\text { for the } 24 \text { questions }\end{array}$ \\
\hline $\begin{array}{c}\text { EGACE } \\
\text { Pereira (2012) Brazil }\end{array}$ & $\begin{array}{c}\text { Principles of LC by Koskela } \\
\text { (1992) \& framework by } \\
\text { Carvalho (2008) }\end{array}$ & $\begin{array}{c}1 \text { Introduction } \\
2 \text { Reduce the share of non- } \\
\text { value-adding activities } \\
3 \text { Increase output value } \\
\text { through systematic } \\
\text { consideration of customer } \\
\text { requirements } \\
4 \text { Reduce variability }\end{array}$ & $\begin{array}{l}\text { Questionnaire with } \\
40 \text { questions, completed by } \\
\text { construction professionals } \\
\text { through online survey }\end{array}$ & $\begin{array}{l}\text { Each question has different } \\
\text { alternative answers like } \\
\text { true or false and intensity } \\
\text { range with three levels. No } \\
\text { result scale has been } \\
\text { presented }\end{array}$ & $\begin{array}{l}\text { No presentation of the } \\
\text { results model is proposed }\end{array}$ \\
\hline
\end{tabular}


Chart 1. Continued..

\begin{tabular}{|c|c|c|c|c|c|}
\hline $\begin{array}{l}\text { MODEL AUTHOR } \\
\text { (YEAR) COUNTRY }\end{array}$ & INFLUENCED BY & MAIN EVALUATION FACTORS & APPLICATION METHOD & RESULTS SCALE & $\begin{array}{l}\text { VISUAL RESULTS } \\
\text { PRESENTATION }\end{array}$ \\
\hline & & $\begin{array}{l}5 \text { Reduce the cycle time } \\
6 \text { Simplify by minimizing the } \\
\text { number of steps and parts } \\
7 \text { Increase output flexibility } \\
8 \text { Increase process } \\
\text { transparency } \\
9 \text { Focus control on the } \\
\text { complete process } \\
10 \text { Build continuous } \\
\text { improvement into the } \\
\text { process }\end{array}$ & & & \\
\hline $\begin{array}{c}\text { PALC } \\
\text { Etges et al. (2013) } \\
\text { Brazil }\end{array}$ & $\begin{array}{l}\text { Principles of LC by Koskela } \\
\text { (1992) \& principles of LT by } \\
\text { Womack and Jones (1997) }\end{array}$ & $\begin{array}{c}1 \text { Human Resources (HR) } \\
2 \text { Continuous } \\
\text { Improvement (CI) } \\
3 \text { Work Standardization (WS) } \\
4 \text { Work Safety (JS) } \\
5 \text { Layout (LA) } \\
6 \text { Quality Control (QC) } \\
7 \text { Logistics and Supply Chain } \\
\text { Management (LSC) } \\
8 \text { Information Technology } \\
\text { and Communication (ITC) } \\
9 \text { Pull Production (PP) } \\
10 \text { Visual Management (VM) } \\
11 \text { Production Planning and } \\
\text { Control (PPC) } \\
12 \text { Sustainability (SUS) } \\
13 \text { Design Management and } \\
\text { Product Development } \\
\text { (DMPD) } \\
14 \text { Costs Control (CC) } \\
15 \text { Continuous Flow (CF) }\end{array}$ & $\begin{array}{l}\text { A protocol with } \\
103 \text { statements distributed } \\
\text { over } 15 \text { categories were } \\
\text { the LC practices are } \\
\text { described and with } \\
\text { scientific reference set out } \\
\text { the LC principle. The } \\
\text { categories has different } \\
\text { weights that are } \\
\text { considered to the final } \\
\text { evaluation by a range from } \\
0 \text { to } 4 .\end{array}$ & $\begin{array}{l}\text { Range of tree values of } 0 ; \\
0,5 \text { and } 1 \text { and also non- } \\
\text { applicable option, the } \\
\text { statement classified with } \\
\text { non-applicable is not } \\
\text { considerate to the final } \\
\text { evaluation. }\end{array}$ & $\begin{array}{l}\text { No presentation of the } \\
\text { results model is proposed, } \\
\text { but has a equation for the } \\
\text { final performance score } \\
\text { considering each evaluated } \\
\text { statement, it's weight and } \\
\text { the non-applied } \\
\text { statements. }\end{array}$ \\
\hline
\end{tabular}


Chart 1. Continued..

\begin{tabular}{|c|c|c|c|c|c|}
\hline $\begin{array}{l}\text { MODEL AUTHOR } \\
\text { (YEAR) COUNTRY }\end{array}$ & INFLUENCED BY & MAIN EVALUATION FACTORS & APPLICATION METHOD & RESULTS SCALE & $\begin{array}{l}\text { VISUAL RESULTS } \\
\text { PRESENTATION }\end{array}$ \\
\hline $\begin{array}{c}\text { LCMM } \\
\text { Nesensohn (2014) } \\
\text { UK }\end{array}$ & $\begin{array}{l}\text { Principles of LC by Koskela } \\
\text { (1992) }\end{array}$ & $\begin{array}{c}1 \text { Leadership } \\
2 \text { Philosophy } \\
3 \text { People } \\
4 \text { Processes \& system } \\
5 \text { Outcomes \& outputs } \\
6 \text { Learning }\end{array}$ & $\begin{array}{c}\text { Framework with } \\
75 \text { statements organized in } \\
11 \text { attributes classified in } \\
6 \text { layers, completed by } \\
\text { external evaluator after a } \\
\text { construction site visit and } \\
\text { conversations with } \\
\text { employees, evaluating each } \\
\text { attribute through Likert } \\
\text { scale from } 0 \text { to } 4 \text {. The } \\
\text { layers have weights which } \\
\text { are multiplied by the } \\
\text { lowest value of the } \\
\text { attributes belonging to } \\
\text { each layer. }\end{array}$ & $\begin{array}{l}\text { Range of absolute values of } \\
5 \text { categories (from } 0 \text { to 4): } \\
\text { Uncertain; Awakening; } \\
\text { Systematic; Integrated; } \\
\text { Challenging }\end{array}$ & $\begin{array}{l}\text { Radar chart with markers, } \\
\text { presenting the evaluation } \\
\text { for the } 6 \text { attributes }\end{array}$ \\
\hline $\begin{array}{l}\text { LATB } \\
\text { Ireland Lean } \\
\text { Construction } \\
\text { Institute } \\
(2015) \\
\text { Ireland }\end{array}$ & $\begin{array}{l}\text { Toyota Production System } \\
\text { \& } \\
\text { Integrated project delivery } \\
\text { by The American Institute } \\
\text { of Architect (2014) }\end{array}$ & $\begin{array}{c}1 \text { Transformational change } \\
2 \text { Integrated project delivery } \\
\text { strategy } \\
\text { 3 Last Planner System } \\
\text { 4 Lean project management }\end{array}$ & $\begin{array}{l}\text { Excel tool that analyze four } \\
\text { main elements based on } \\
\text { the "lean house" with } \\
152 \text { attributes distributed } \\
\text { in } 40 \text { characteristics, every } \\
\text { characteristic is evaluated } \\
\text { on a Linkert scale } \\
\text { from } 0 \text { to } 5\end{array}$ & $\begin{array}{c}\text { Range of absolute values of } \\
6 \text { categories (from } 0 \text { to 5): } \\
\text { Best in class; Integrated; } \\
\text { organized; Ad-hoc; Aware; } \\
\text { Non scored }\end{array}$ & $\begin{array}{l}\text { Four radar chart with } \\
\text { markers, one for each main } \\
\text { element, presenting the } \\
\text { evaluation of the } \\
40 \text { characteristics } \\
\text { described }\end{array}$ \\
\hline $\begin{array}{c}\text { MMDPLC } \\
\text { Soto Becerra (2016) } \\
\text { Chile }\end{array}$ & $\begin{array}{l}\text { Principles of LC by Koskela } \\
\text { (1992) \& principles of LT by } \\
\text { Womack and Jones (1997) } \\
\text { \& Diekmann et al. (2004) } \\
\text { proposed concepts }\end{array}$ & $\begin{array}{c}1 \text { Waste disposal } \\
2 \text { Standardization } \\
3 \text { Culture / people } \\
4 \text { Customer focus } \\
5 \text { Continuous improvement / } \\
\text { Quality }\end{array}$ & $\begin{array}{l}\text { Self-assessment } \\
\text { questionnaire applied by } \\
\text { internal evaluator, } \\
\text { evaluating } 16 \text { LC practices } \\
\text { on a Likert scale from } 0 \text { to } \\
\text { 5, organized in } 6 \text { principle. }\end{array}$ & $\begin{array}{l}\text { Range of absolute values of } \\
6 \text { categories (from } 0 \text { to 5): } \\
\text { Sustainable; Integrated; } \\
\text { Established; Formal; Initial; } \\
\text { Non existent }\end{array}$ & $\begin{array}{l}\text { No presentation of the } \\
\text { results model is proposed }\end{array}$ \\
\hline $\begin{array}{c}\text { ALC } \\
\text { Sweis et al. (2016) } \\
\text { Jordan }\end{array}$ & $\begin{array}{l}\text { Diekmann et al. (2004) } \\
\text { proposed concepts }\end{array}$ & $\begin{array}{l}1 \text { Customer focus } \\
2 \text { Culture/people } \\
3 \text { Workplace organization } \\
\text { and standardization }\end{array}$ & $\begin{array}{c}\text { Questionnaire with } \\
33 \text { questions, applied by } \\
\text { external interviewer } \\
\text { evaluating each question }\end{array}$ & No results scale & $\begin{array}{c}\text { Radar chart with markers } \\
\text { presenting the evaluation } \\
\text { of the } 5 \text { principles with five } \\
\text { absolute levels }\end{array}$ \\
\hline
\end{tabular}


Chart 1. Continued...

\begin{tabular}{|c|c|c|c|c|c|}
\hline $\begin{array}{l}\text { MODEL AUTHOR } \\
\text { (YEAR) COUNTRY }\end{array}$ & INFLUENCED BY & MAIN EVALUATION FACTORS & APPLICATION METHOD & RESULTS SCALE & $\begin{array}{l}\text { VISUAL RESULTS } \\
\text { PRESENTATION }\end{array}$ \\
\hline & & $\begin{array}{l}4 \text { Eliminate waste } \\
5 \text { Continuous } \\
\text { improvement/built-in quality }\end{array}$ & $\begin{array}{l}\text { through Likert scale } \\
\text { from } 0 \text { to } 5 \text { and N/A }\end{array}$ & & \\
\hline $\begin{array}{c}\text { LCI Lean IPD } \\
\text { Lean Construction } \\
\text { Institute (2016) USA }\end{array}$ & $\begin{array}{l}\text { Principles of LC by Koskela } \\
\text { (1992) \& principles of LT by } \\
\text { Womack and Jones (1997) } \\
\text { \& Lean Construction } \\
\text { Institute (2013) }\end{array}$ & $\begin{array}{l}1 \text { Transformational change } \\
2 \text { Lean project delivery } \\
\text { methods and management } \\
3 \text { Integrated project delivery } \\
4 \text { Lean project delivery and } \\
\text { Last Planner System }\end{array}$ & $\begin{array}{l}\text { Excel tool that analyze four } \\
\text { main elements with } 191 \\
\text { attributes distributed in } 36 \\
\text { characteristics, every } \\
\text { characteristic is evaluated } \\
\text { on a Linkert scale } \\
\text { from } 0 \text { to } 5\end{array}$ & $\begin{array}{l}\text { Range of absolute values of } \\
6 \text { categories (from } 0 \text { to 5): } \\
\text { Innovating; Teaching; } \\
\text { Competent; Learning; } \\
\text { Aware; Unaware }\end{array}$ & $\begin{array}{l}\text { Four radar chart with } \\
\text { markers, one for each main } \\
\text { element, presenting the } \\
\text { evaluation of the } \\
36 \text { characteristics } \\
\text { described and one radar } \\
\text { summary graph with four } \\
\text { main element punctuation }\end{array}$ \\
\hline $\begin{array}{c}\text { EISLC } \\
\text { Li et al. (2016) China }\end{array}$ & $\begin{array}{l}\text { Principles of LC by Koskela } \\
\text { (1992) \& principles of LT by } \\
\text { Womack and Jones (1997) } \\
\text { \& LC tools }\end{array}$ & $\begin{array}{l}1 \text { Last Planner System (LPS) } \\
2 \text { Visible Management (VM) } \\
3 \text { Conference Management } \\
\text { (CM) } \\
\text { 4 Just in Time (IIT) } \\
5 \text { Concurrent Engineering } \\
\text { (CE) } \\
6 \text { Total Quality Management } \\
\text { (TQM) } \\
75 \text { and 6S on-site } \\
\text { management }\end{array}$ & $\begin{array}{c}\text { Framework with } 26 \\
\text { statements organized in } 7 \\
\text { instruments evaluated in a } \\
\text { Likert scale from } 0 \text { to } 5 \text { by } \\
\text { different company actors } \\
\text { in interview }\end{array}$ & $\begin{array}{l}\text { No results scale, just table } \\
\text { with percentage values }\end{array}$ & No visual presentation \\
\hline $\begin{array}{c}\text { DOLC } \\
\text { Carvalho and Scheer } \\
\text { (2017) Brazil }\end{array}$ & $\begin{array}{l}\text { Principles of LC by Koskela } \\
\text { (1992) \& framework by } \\
\text { Carvalho (2008) }\end{array}$ & $\begin{array}{l}1 \text { Reduce the share of non } \\
\text { value-adding activities } \\
2 \text { Increase output value } \\
\text { through systematic } \\
\text { consideration of customer } \\
\text { requirements } \\
3 \text { Reduce variability } \\
4 \text { Reduce the cycle time } \\
5 \text { Simplify by minimizing the } \\
\text { number of steps and parts } \\
6 \text { Increase output flexibility }\end{array}$ & $\begin{array}{c}6 \text { questionnaire, with } \\
\text { about } 30 \text { questions each, } \\
\text { applied by external } \\
\text { evaluators to internal } \\
\text { agents (designer, engineer, } \\
\text { worker, director, supplier) } \\
\text { and external (client) of the } \\
\text { company. Free answers } \\
\text { (qualitative) that the } \\
\text { evaluator should quantify }\end{array}$ & $\begin{array}{l}\text { Percentage scale of } \\
4 \text { classes with } 3 \text { subclasses } \\
\text { each (from "D" to "AAA"). } \\
\text { The steps are uniform } \\
\text { except the lowest grade } \\
\text { that is bigger than the } \\
\text { others }\end{array}$ & $\begin{array}{l}\text { Radar chart filled out, } \\
\text { presenting the evaluation } \\
\text { for the } 11 \text { principles of LC }\end{array}$ \\
\hline
\end{tabular}


Chart 1. Continued...

\begin{tabular}{|c|c|c|c|c|c|}
\hline $\begin{array}{l}\text { MODEL AUTHOR } \\
\text { (YEAR) COUNTRY }\end{array}$ & INFLUENCED BY & MAIN EVALUATION FACTORS & APPLICATION METHOD & RESULTS SCALE & $\begin{array}{l}\text { VISUAL RESULTS } \\
\text { PRESENTATION }\end{array}$ \\
\hline & & $\begin{array}{l}7 \text { Increase process } \\
\text { transparency } \\
8 \text { Focus control on the } \\
\text { complete process } \\
9 \text { Build continuous } \\
\text { improvement into the } \\
\text { process } \\
10 \text { Balance flow } \\
\text { improvement with } \\
\text { conversion improvement } \\
11 \text { Benchmark }\end{array}$ & $\begin{array}{l}\text { on a Likert scale } \\
\text { from } 0 \text { to } 3\end{array}$ & & \\
\hline $\begin{array}{l}\text { CC\&FD for LC SMEs } \\
\text { Tezel et al. (2017) UK }\end{array}$ & $\begin{array}{l}\text { Principles of LC by Koskela } \\
\text { (1992), principles of LT by } \\
\text { Womack and Jones (1997) } \\
\text { and conducted interviews }\end{array}$ & $\begin{array}{c}\text { Current Condition } 1 \text { Project } \\
\text { delivery } \\
2 \text { Process } \\
3 \text { Training } \\
4 \text { Project governance } \\
5 \text { Supply chain } \\
\text { Future Direction } 1 \text { Project } \\
\text { delivery } \\
2 \text { Process } \\
3 \text { Training } \\
4 \text { Project governance } \\
5 \text { Supply chain }\end{array}$ & $\begin{array}{l}2 \text { questionnaires, one for } \\
\text { evaluate current conditions } \\
\text { and other to evaluate } \\
\text { future directions, the } \\
\text { questions are distributed } \\
\text { in } 5 \text { categories. The first } \\
\text { one with } 31 \text { statements } \\
\text { and the second with } 40 \text {. } \\
\text { each statement are } \\
\text { evaluated on Likert scale } \\
\text { from } 1 \text { to } 5\end{array}$ & $\begin{array}{l}\text { No results scale, just table } \\
\text { with percentage values }\end{array}$ & No visual presentation \\
\hline $\begin{array}{c}\text { LCR } \\
\text { Brandão et al. (2018) } \\
\text { Brazil \& Germany }\end{array}$ & $\begin{array}{c}\text { Principles of LC by Koskela } \\
\text { (1992) \& principles of LT by } \\
\text { Womack and Jones (1997) } \\
\text { \& framework by } \\
\text { Hofacker et al. (2008) }\end{array}$ & $\begin{array}{c}1 \text { Client focus } \\
2 \text { Waste consciousness } \\
3 \text { Quality } \\
4 \text { Material flow } \\
5 \text { Organization, planning and } \\
\text { info-flow } \\
6 \text { Continuous improvement }\end{array}$ & $\begin{array}{l}\text { Questionnaire with } 30 \\
\text { questions, completed by } \\
\text { external evaluator after a } \\
\text { hour in a construction site } \\
\text { visit evaluating each } \\
\text { question in quantitative } \\
\text { way through a Likert scale } \\
\text { from } 0 \text { to } 4\end{array}$ & $\begin{array}{l}\text { Percentage scale of } \\
4 \text { classes with } 3 \text { subclasses } \\
\text { each (from "d" to "aaa"). } \\
\text { The step of the grade } \\
\text { gradually lower while the } \\
\text { grade get higher }\end{array}$ & $\begin{array}{l}\text { Radar chart filled out, } \\
\text { presenting the evaluation } \\
\text { for the } 6 \text { factors }\end{array}$ \\
\hline
\end{tabular}

Source: Based on Rodegheri and Serra (2019). 
Researchers apply four of the twelve MM from Chart 1 and results are presented and discussed in this paper. These four are best suited to answer the question previously quoted. To this selection, a content analysis based on Elo and Kyngäs (2008) was conducted to evaluate the twelve methods thought the category and classification presented in Chart 2. To the MM evaluation, a color scale had been developed, Figure 1 present the adopted colors and each general classification criteria. As an example of a classification scale for the first category "Bibliographic base on", we consider that scale goes from the lowest classification (red) "Unknown bibliography" to the highest classification (dark green) "Reputable bibliography".

Chart 2. Maturity Models classification
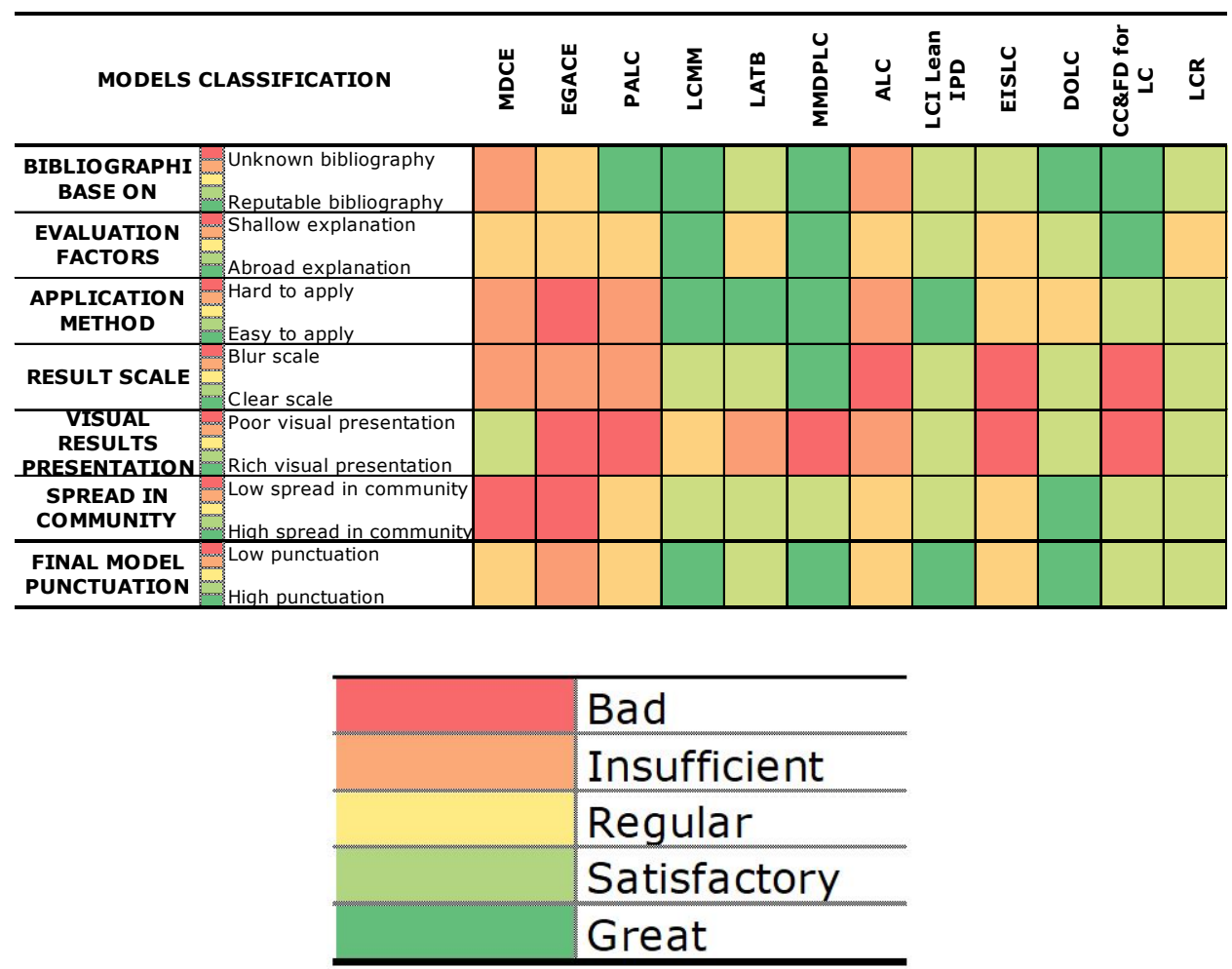

Figure 1. Maturity Models classification scale

The four MM that had the best average to the six categories received the greatest classification, as shown in Chart 2 as dark green in the final model punctuation. These four MM were applied to the selected project and are best presented below. The application specificities will be detailed in the next section.

a) Lean Construction Maturity Model (LCMM): developed from a consult with professionals from six countries and focus groups with experts on LC by the UK, based on a neverending journey in LC progress. Nesensohn (2014) propose statements related to LC who should be evaluated after a site visit and dialogues with agents of the project. The statements are distributed in attributes, each attribute is evaluated with the lowest value of the statements that support it. The attributes have different weights which could be modified according to the company values and vision or used as presented by the MM author (Nesensohn et al., 2014; Nesensohn, 2017). This MM could be used for selfassessment or external assessment (Nesensohn et al., 2015). The results are presented in the radar chart with five ranking levels for each attribute.

b) Maturity Model for Development of Lean Construction Principles (MMDPLC): a Chilean self-assessment tool developed by Soto Becerra (2016) that check the company 
expectation and effective adherence to LC principles and practices, respectively. As a selfassessment tool, the evaluation is based on a worker daily experience in six ranking levels. The results are not presented visually.

c) LCI Lean IPD Health and Maturity Assessment Tool (LCI Lean IPD): Excel tool set out by the United States Lean Construction Institute (2016) based on LC, LT, LPS and Integrated Project Delivery (IPD). It analyzes four main elements divided into 36 characteristics with 191 attributes. Each characteristic is evaluated in six ranking levels, the results are presented in a spider diagram for each main element and a radar summary graph with the four main elements.

d) Degree of Lean Construction (DOLC): Carvalho and Scheer (2017) use six questioners for internal (designer, engineer, worker, directors, and client) and external (supplier) company agents, based on Carvalho (2008). An external interviewer that knows LC to answer doubts of the interviewees makes the evaluation. The results are presented in a radar chart with the average values of all interviewees for each LC principle with four ranking levels.

\section{METHOD}

This paper consists of a case study with an application of four MM in the same project in the same period. The results obtained with these four models were compared in content analysis to select the suitable MM to evaluate Brazilian construction companies at the start level of a lean journey. Figure 2 presents the summarily paper development and it is followed in detailed.

\section{PREPARING}

Literature review about Lean Construction, Maturity Models, Performance Measurement System

\begin{tabular}{|c|}
\hline Selection of papers about the development and application of Maturity Models \\
\hline Selection of Maturity Model to be presented (Chart 1) \\
\hline Selection of Maturity Model to be applied in the case study (Chart 2) \\
\hline
\end{tabular}

ORGANIZING

\begin{tabular}{|c|}
\hline Definition of project and agents to the case study \\
\hline A case study conducted through the Maturity Models application (Figure 3 to 9) \\
\hline Development of evaluation criteria and data coding through content analysis \\
\hline REPORTING \\
\hline Comparison of Maturity Models application results (Figure 10) \\
\hline Presentation of evaluation criteria to elect the suitable Model and discusion (Chart 3) \\
\hline Presentation of the suitable Maturity Models to this scenario \\
\hline
\end{tabular}

Figure 2. Paper development Source: Based on Elo and Kyngäs (2008).

Literature review was carried out on scientific document basis as well as in LC institutes and organizations, searching for "evaluation lean construction", "lean construction indicator", "performance measurement systems lean construction", "performance indicator lean construction" and "maturity model lean construction", were found papers, programs, and documents from 2000 to 2019. The selected MM to apply in this research were the best 
classified as shown in Chart 2 and has a comprehensive performance data applying LC principles in the studied company. Thus, the selected models were developed by Nesensohn (2014), Soto Becerra (2016), Lean Construction Institute (2016) and Carvalho and Scheer (2017).

The enterprise studied is located in Sorocaba, São Paulo, Brazil and it is a small company founded in 2015 from joined a project office and residential construction company. The chosen project is a residential community with fifty houses connived by investors who were the main customer and had been financing by public Brazilian house programs. While the field research, one of the authors was performing as professional in the same construction site and the construction was in the finishing phase, with reduced stock, workers and material flow. This company does not use formally LC; even though some professionals know it. Researchers could find some use of it in an unreasonable way and some limitations, due to the project nature and fomented federal program requirements.

For MM application, some notes are made:

a) Lean Construction Maturity Model (LCMM): were used the weights of the attributes proposed by the method author, the results will be presented in two radar chart, the first one considering the method evaluation for each attribute (the lowest statement evaluated) and for the second, the attribute evaluation is the average of statements value. The percentage was adopted for the scale results, respecting the original five proposed levels in absolute values. The method considers that the project just grows to another maturity level after filleted out all gaps of the current level. This makes the tool rough to companies starting LC journey in its first evaluation, because of that, the researchers use both presentation results, the original (rough) and adapted (gentle).

b) Maturity Model for Development of Lean Construction Principles (MMDPLC): the company does not use LC principles, so the evaluation of adherence expectations of lean principles was done by researchers' expectations about what could be seen in the construction site. The results are presented on the radar chart with six ranking levels in percentage and practice evaluation was done by statements average value.

c) LCI Lean IPD Health and Maturity Assessment Tool (LCI Lean IPD): the original radar summary graph had been adapted to be presented with percentage scale and in a radar chart presenting the six ranking levels.

d) Degree of Lean Construction (DOLC): five questionnaires were applied (designer, engineer, worker, director, and client), the supplier questionnaire could not be filleted out because there was no supplier adherence to these research, nevertheless the authors consider the data collected enough for de research propose.

\section{RESULTS AND DISCUSSION}

Following the MM application, researchers analyze the data collected and the graphic results to present this section figures. There are the original and adapted radar charts were the results can be compared. Every chart presents the evaluated factors, classification-ranking levels, project adherence of each factor and final project classification. All data is presented in percentage to easily comparison between each method.

The company adhesion to the evaluated attributes is given by the grey figure that covers the ranking level, in these four presented methods it is around the central point for the lowest scale values. The final adherence percentage for the attributes evaluated in each method, showed at the label of the charters, confirm that the project use, somehow, the LC practices although the LC culture is not formally applied in the company daily.

Figure 3 presents a radar chart based on the original Nesensohn (2014) method, considering the lowest statement value for each attribute, were project adhesion to evaluated principles is 20\%. Figure 4 presents' adapted Nesensohn' (2014) radar char, with attributes evaluation by statements average value, were project had $35 \%$ adhesion, shown that original evaluation method is rough in fact. 


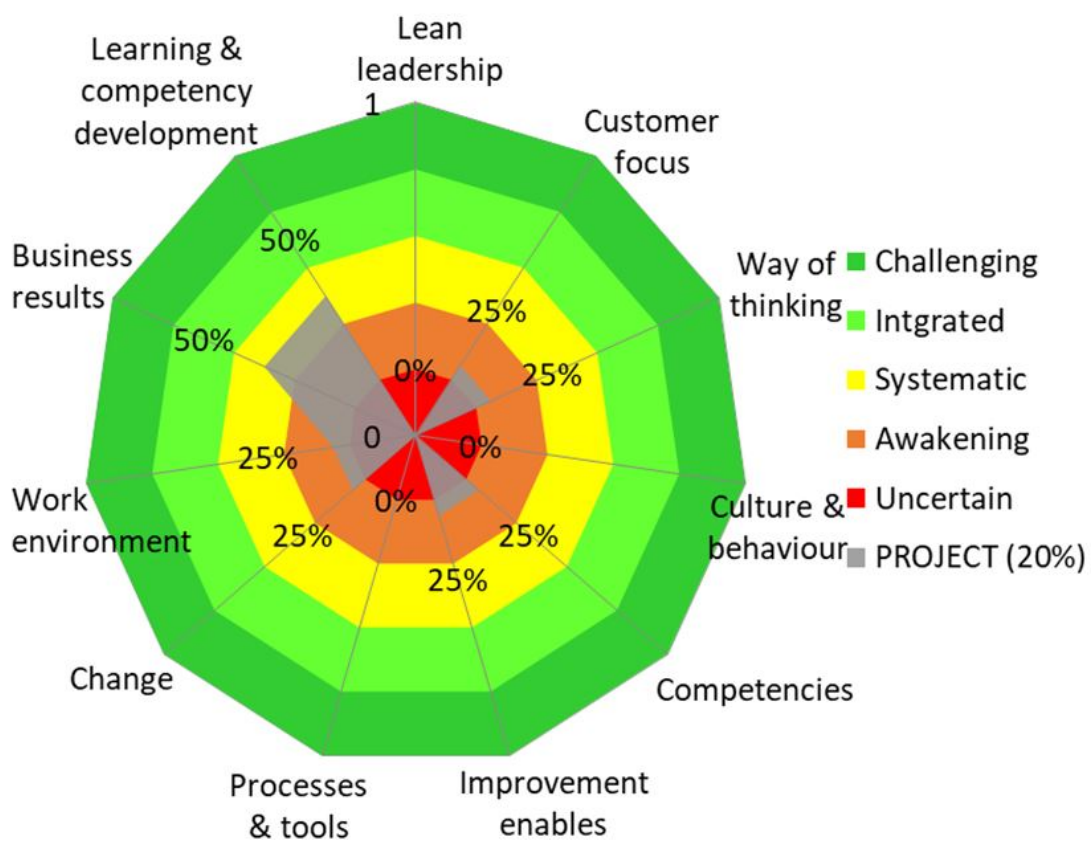

Figure 3. Project evaluation with LCMM original method Source: Adapted from Nesensohn (2014).

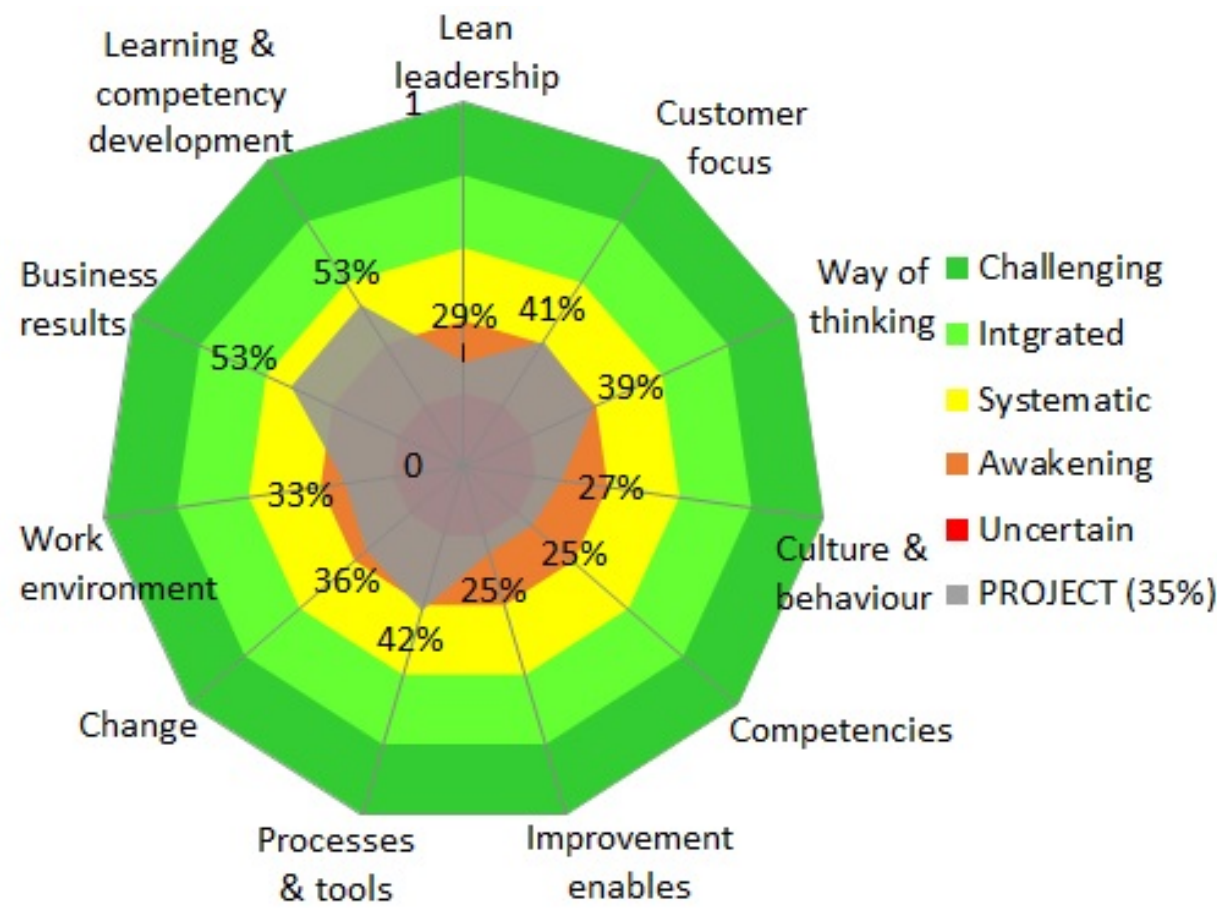

Figure 4. Project evaluation with LCMM adapted method Source: Adapted from Nesensohn (2014).

Figure 5 presents Soto Becerra (2016) radar chart where the project had $45 \%$ adhesion to LC evaluated practices. This method does not present a graphic representation, so the authors adapted the results for this radar chart to better compare with the other methods. 


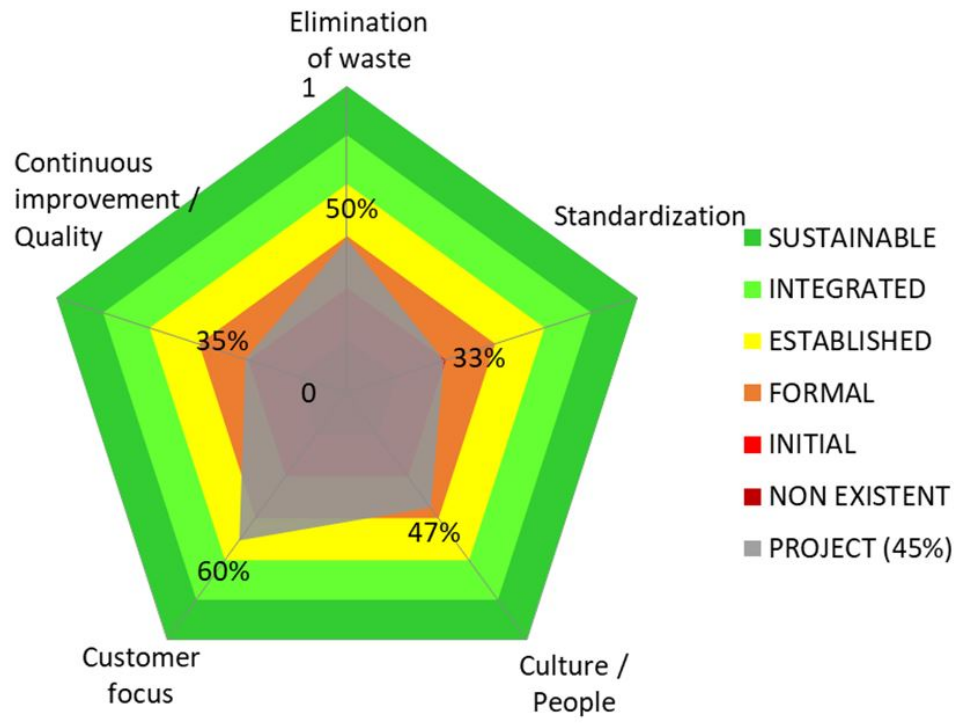

Figure 5. Project evaluation with MMDPLC method

Figure 6 and Figure 7 present original graphic evaluation from US LCI (Lean Construction Institute, 2016). Figure 6 presents four radar charts of each main factor evaluation with their statements. Figure 7 presents the summary results of this method. It can be observed that two graphics presented in Figure 6 has the same colors, as two areas in Figure 7, it is because this method initially divides assessment elements into three triangle edges: Transformational Change, Integrated Project Delivery Strategy and Lean Project Delivery Methods \& Management. The last element is divided to be assessed in two practices: Last Planner System and Methods \& Management so they have the same color. Figure 8 presents US LCI (Lean Construction Institute, 2016) adapted results of 36\% adhesion of evaluated elements, like Figure 6 but in percentage scale for the best comparison with the other methods.

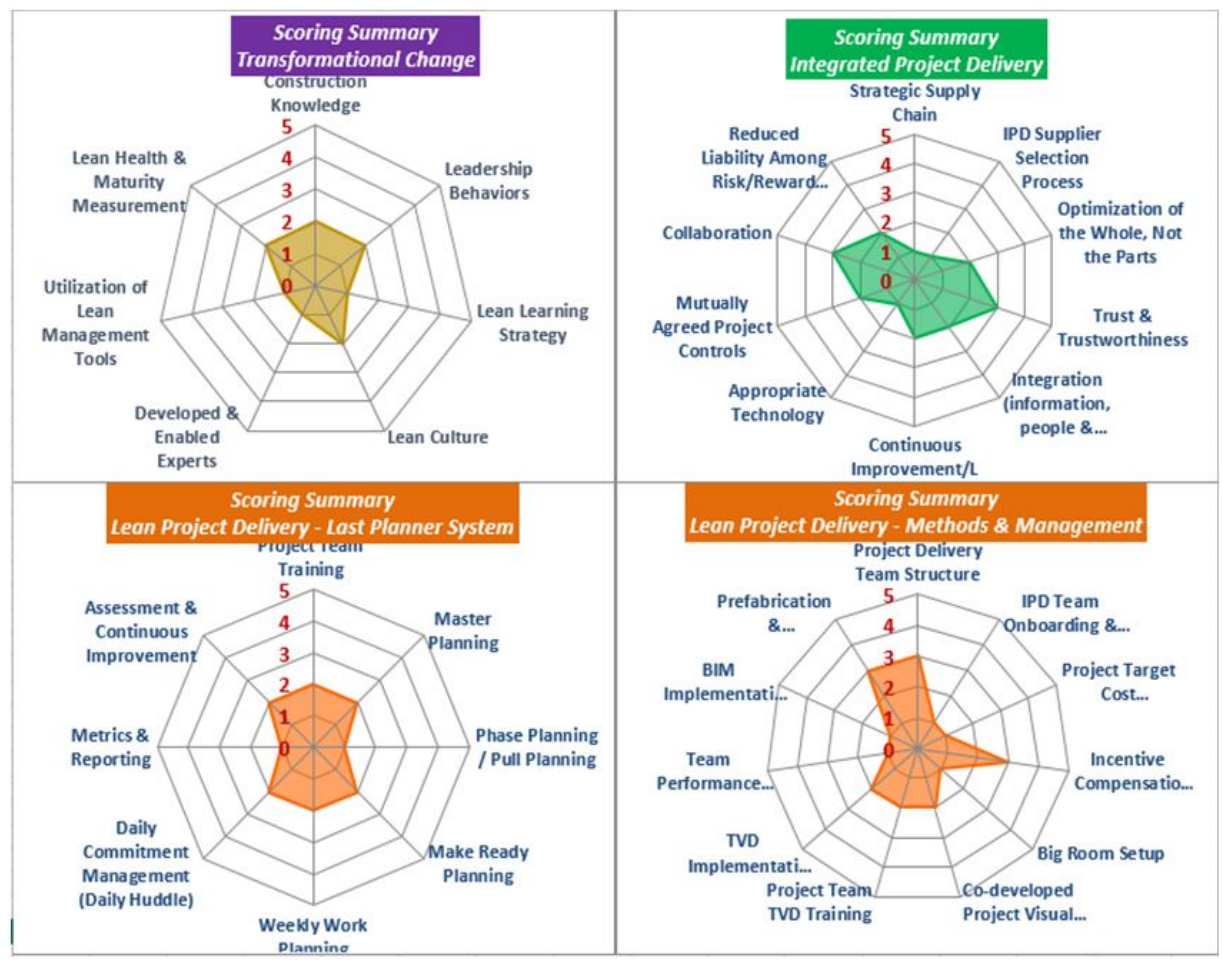

Figure 6. Project evaluation with LCI Lean IPD original method

Source: Adapted from US LCI (Lean Construction Institute, 2016). 


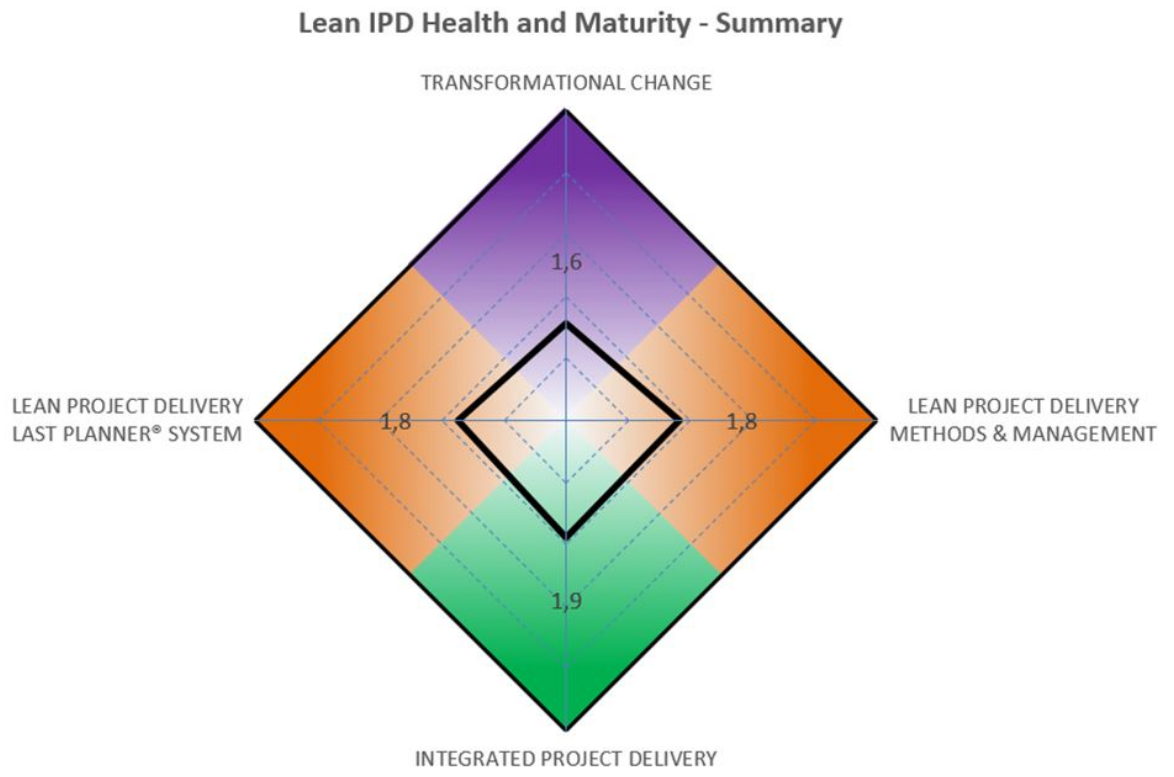

Figure 7. Project evaluation with LCI Lean IPD original method - Summary Source: Adapted from US LCI (Lean Construction Institute, 2016).

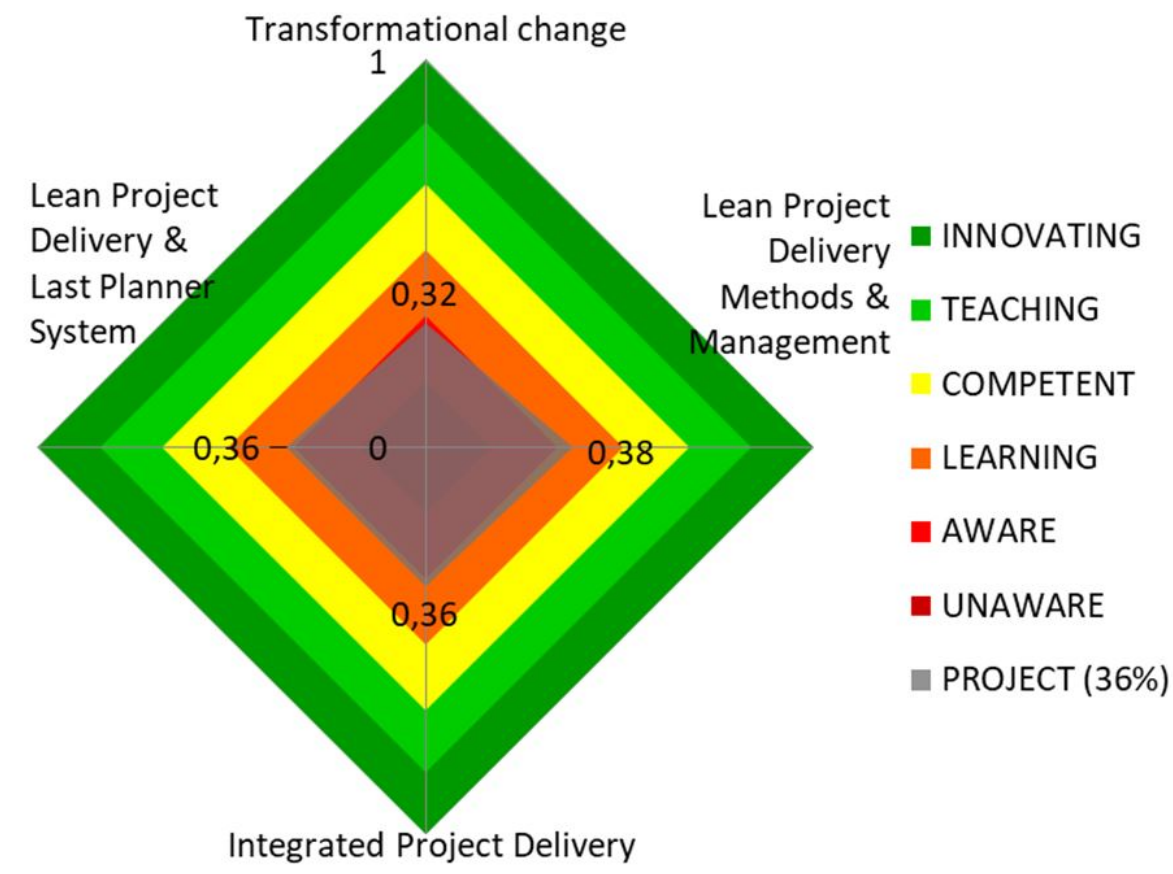

Figure 8. Project evaluation with LCI Lean IPD adapted method Source: Adapted from US LCI (Lean Construction Institute, 2016).

Figure 9 presents Carvalho's (2008) model original radar chart result with 56\% adhesion to $L C$ principles. 


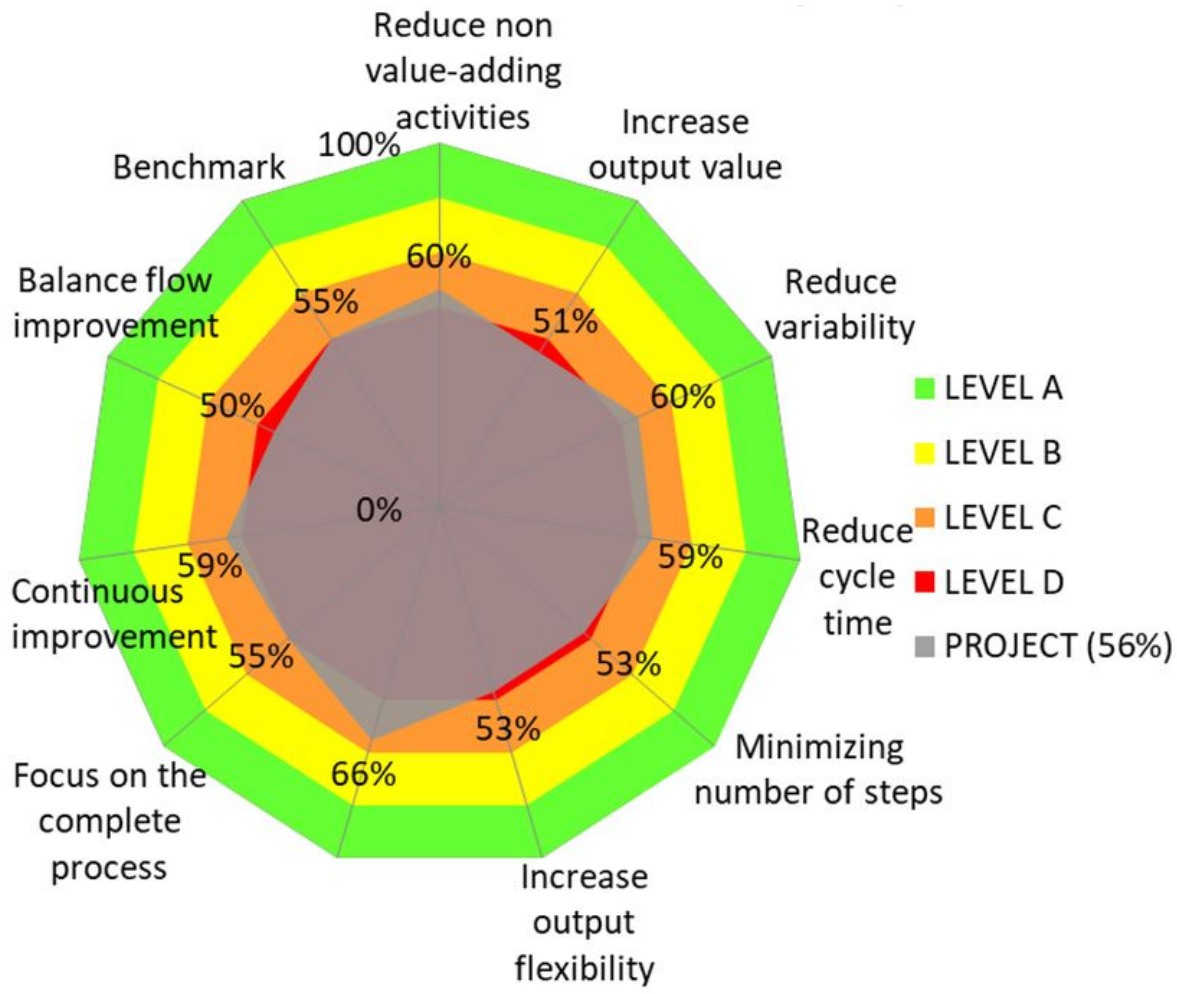

Figure 9. Project evaluation with DOLC method Source: Adapted from Carvalho (2008).

The four MM was selected for this paper because their spread attributes evaluated but they have differences with each other. To better discuss the obtained results, will be under analysis of the four methods and the adapted evaluation provided by the average values from LCMM, as shown in Figure 4.

One of the differences between these five LC evaluations is the final scale results. Figure 10 presents the comparison of the results showing the company position for each method. DOLC scale presented in Figure 10 is original from the method, the others had been adapted to a percentage scale, as described in the previous section. DOLC is the only one that the levels do not has a homogeneous ascension.

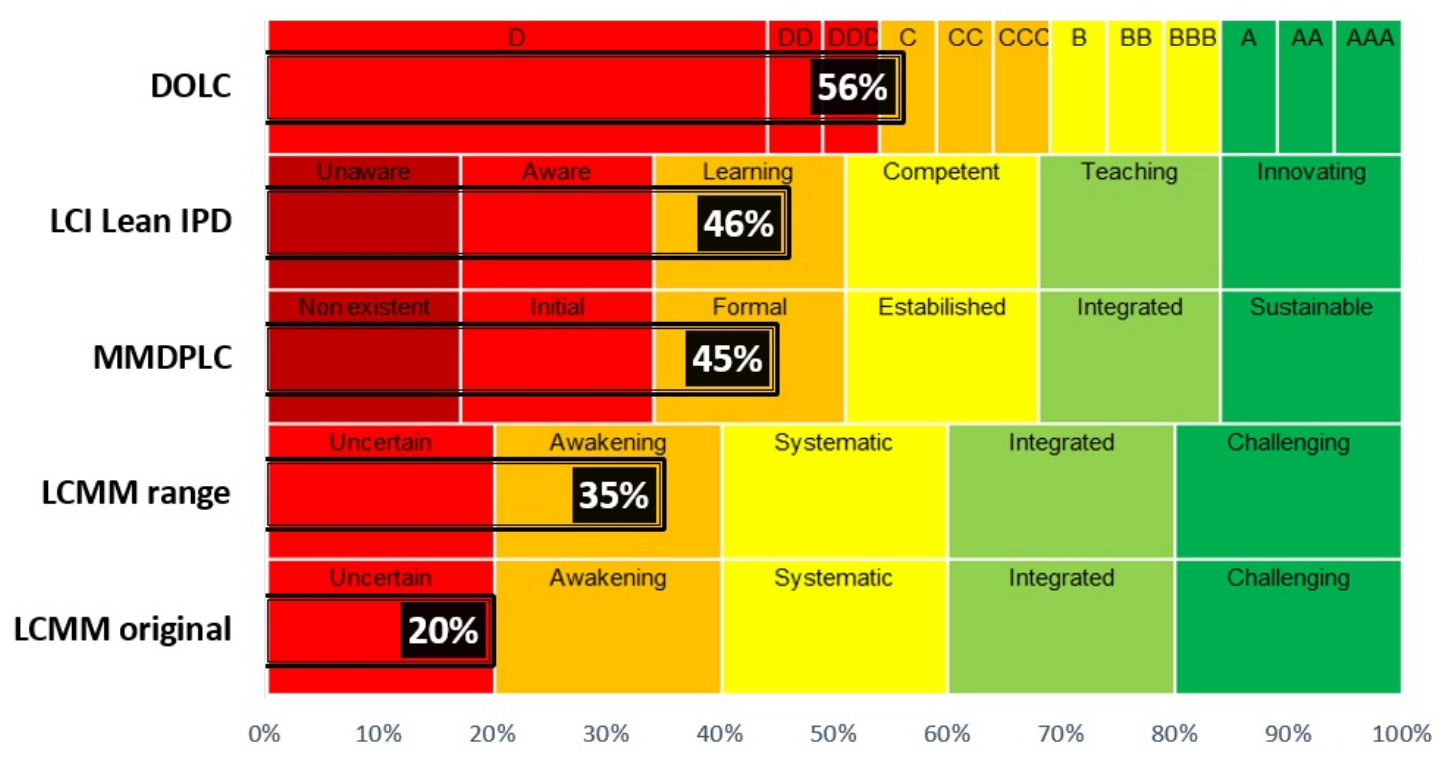

Figure 10. Comparison between scale results of utilized MM 
It can be observed that DOLC was the only one that the company adhesion of LC had been higher than $50 \%$. The gradual score ascension of this method could be better than homogeneous ascension because of the $80 / 20$ rule (aka the Pareto Principle), LCI Lean PID (Lean Construction Institute, 2016) affirm that "as performance increases it is much harder to increase performance" and remind that the Pareto Principle is focused on the whole optimization, gradually improving performance in overall, not in separate parts. Beyond more ranking levels make the MM scale greater sensitive to the small progress in the journey, which can break the resistance and difficulty to assimilate lean behavior and greater employee compliance for lean philosophy (Sousa et al., 2017).

Regarding the five values presented in Figure 10, the classification average is $40 \%$, it confirms that the methods used in this research suit for starting lean journey enterprises, since the project evaluated do not use LC formally. As quoted earlier, Brazil construction companies has low knowledge and application of LC and LT, added to this, more than 90\% construction industry establishments are Small-Medium Sized Enterprises (SME) (Câmara Brasileira da Indústria da Construção, 2017; Serviço Brasileiro de Apoio às Micro e Pequenas Empresas, 2018). Moreover, Tezel et al. (2017) stand out the economic importance of SME in construction and its project management perspective that rarely has been investigated. Therefore initiatives to boost the application of LC, such as Highways England (HE), are fundamental to support the growth of the construction industry and economy.

Furthermore, Zhou (2016) present that increased productivity and efficiency is the primary benefit of lean to the United States construction SME. Despite this, many Critical Success Factors (CSF) and barriers are found to implement LM in SME of different sectors, the four CSF most found in the literature are the leadership adhesion, the company culture, the competence and ability to improve LP and the training and education process (Pereira and Tortorella, 2018). The most common barriers to LM improvement in SMEs are the lack of understanding of lean benefits, the employees' resistance to change, the difficult to adapt LM concepts and practices to the company's culture and the failure of previous improvement projects (Pereira and Tortorella, 2018).

A content analysis was conducted with the results of the five applications in the case study. Six evaluation criteria were defined: application time, team engagement to the research, template, abroad approach regarding the LC diversity, and the final scale results. Those six criteria were selected after the application of the MM and outcome discussion between the researchers and some of the company actors who attend this research. They were considered the most relevant to the company engagement to evaluate the lean journey and to the project evaluation. To classify each criterion, a color scale was used, as presented in Figure 1. Chart 3 presents the evaluation of the five applied models and the higher and lowest bonders for the color scale to each criterion.

Chart 3. Maturity Models evaluation

\begin{tabular}{|c|c|c|c|c|c|}
\hline MODELS CLASSIFICATION & Чُ & 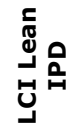 & $\frac{u}{\sum_{0}}$ & 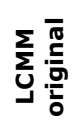 & 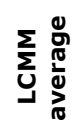 \\
\hline APPLICATION 尸song time/no flexible $_{\text {Short time/flexible }}$ & & & & & \\
\hline \begin{tabular}{c|c} 
TEAM & $\exists^{\text {Too much engagement }}$ \\
ENGAGEMENT & $\exists_{\text {Enough engagement }}$
\end{tabular} & & & & & \\
\hline \begin{tabular}{l|l} 
DYNAMIC & $\Xi_{\text {TEMPLATE }}^{\text {Poomplate/layout }}$ \\
TEood template/layout
\end{tabular} & & & & & \\
\hline $\begin{array}{c}\text { BROAD, wITH } \\
\text { EXAMPLE }\end{array} \exists_{\text {Abroad explanation }}^{\text {Shallow explanation }}$ & & & & & \\
\hline $\begin{array}{c}\begin{array}{c}\text { CLEAR SCORE } \\
\text { LEVELS }\end{array} \\
\end{array}$ & & & & & \\
\hline $\begin{array}{l}\text { SCORE } \\
\text { WEIGHT }\end{array}$ & & & & & \\
\hline \begin{tabular}{c|l}
$\begin{array}{c}\text { FINAL MODEL } \\
\text { SCORE }\end{array}$ & Low punctuation \\
\end{tabular} & & & & & \\
\hline
\end{tabular}


About application, were considered the amount of application time and if the method is flexible to be evaluated by an external or internal agent. DOLC demands a great deal of time for application and analysis results and MMDPLC demands the shorter time application. LCI Lean IPD and LCMM have similar implementation time. LCMM, MMDPLC, and LCI Lean IPD allow self-assessment while DOLC does not.

To this research, too much team engagement was considered bad for the MM use. DOLC is the one that needs greater adhesion of the professional agents. The others MM does not demand too much team engagement to be applied. As well as for the time application, MMDPLC needs the lowest team engagement.

It was considered that the more dynamic the template, the more interesting the MM for application. LCI Lean IPD and LCMM have better templates and dynamic layout to evaluate each category. MMDPLC has a poor template with just one chart to be filleted and without a graphic result presentation. The questionnaires presented by DOLC are repetitive and make the template long and exhausting as well as not providing a project evaluation chart, only for each interviewee.

The broader the model is and with descriptions about diversity in lean application, the MM was considered more relevant. LCMM and LCI Lean IPD are more intuitive to recognize the use of LC in different ways, moreover, they exemplify some situations, tools use and culture implementation. MMDPLC is abroad about LC use, however, do not present examples and it is not easily assailable by how is starting a lean journey.

The rating scale clarity of the attributes' was considered in each model through the way it presented the evolution level. The scale of LCI Lean IPD and LCMM are well explained in each tool section or attribute, moreover, total and partial tools and culture use are presented in some cases DOLC explain briefly the questions score levels and MMDPLC do not make clear the levels to be assessed.

The project final classification is misrepresented when few levels are used, thus MM with more score levels was considered better. Furthermore, the LC implementation should be based on the company culture, therefore a model that allows coordinating the weight evaluation to the company vision, values, and mission is considered suitable to this research. MMDPLC is the one that has more score levels and LCMM allows weight appropriation to the project culture. In the presented case study, the final project evaluation through LCMM was used by the model propose method and the average of attributes. The model evaluation was considered rough for a starting lean implementation company, therefore, the average LCMM application was judged as suitable to this research than the others MM.

Thus, the content analysis carried out in this research led to the LCMM average method as suited to evaluate the case study presented. LCMM is a consistent model to evaluate LC however has a hard ascending score level. LCI Lean IPD covers the LC diversity but does not allow coordinate the evaluation of company culture. MMDPLC is an easy way to evaluate lean application despite hard to be applied by those who have low lean knowledge. DOLC has great score levels gradually increasing however is exhausting to interview various project agents with so many attributes.Furthermore, DOLC uses structured questionnaires for collecting data that are the focus and directly related to eleven principles described by Koskela (1992). LCMM and MMDPLC understand the LC variations and make the model elucidative as the LT application. LCMM, MMDPLC, and LCI Lean IPD address the growth challenges at every stage, considering the LC journey an endless path. LCMM allows the company to define the attribute weight, thus making a directed diagnosis to its values and vision.

\section{CONCLUSION}

This paper aimed to designate the suitable MM to evaluate LC adhesion in Brazilian construction companies starting on a lean journey. Four MM were used in the same project and the outcomes had been presented and discussed.

The selection of the most suitable MM was given by a content analysis that taking into consideration the application easiness, light adhesion of the participants for the research, tool design, enlightening about LC, rating scale clarity, and final classification levels and weights. Therefore, LCMM had been considered suitable MM to evaluate LC development of Brazilian 
medium-sized construction, either with the original scale ascension or by the use of average attributes scores

LCMM evaluates equally the development of LC culture, technology, and philosophy through the company. These are the three fundamental aspects drawn out in a triangle shape by GEPUC (Salvatierra et al., 2015). This MM is flexible enough to embrace LC diversity practices in different construction sectors and its continuous evolution. LCMM supports LC philosophy and could be used to improve management in construction firms, as an MM, clarify the paths that should be followed for lean philosophy growth by company, showing the continuous challenges of that journey. Allow fitting the model to the company vision, mission, and values through attributes weight and application by an internal or external evaluator.

LCMM is very rough regarding the rise of levels, therefore the authors suggest that, for companies that are new in LC application, the values of the attributes should be used by the average values of their statements. Small evolutions can be misrepresented using the lowest statement value as Nesensohn' (2014) purpose. Moreover, the authors emphasize that more researches with LCMM application are necessary to discuss the attribute weights, the support given to construction management in the lean journey, and the rising level severity.

The GEPUC's Lean Triangle (Salvatierra et al., 2015) emphasizes the value of adherence by all company's levels in LC implementation through culture, philosophy, and technology. Moreover, Tezel et al. (2017) show the lake of support by high management and the low workers' initiative as barriers for LC development in SME. Thereby, Lean Construction Institute (2016) set out an individual assessment tool, a support tool for the LCI Lean IPD Health and Maturity Assessment. It was drawn up to support individual awareness development of knowledge, motivation, and efforts in applying LC principles. This tool considers that the whole company development lies in individual evolution capabilities. Thus, the authors ratify the significance of researches and initiatives that disseminate knowledge in this area for all construction levels, from the academy to the construction site, consequently building a strong construction community.

This research is an initiative to spread lean knowledge in SME of Brazilian construction through the presentation of the suitable MM to evaluate this kind of enterprise in initial steps of LC implementation. Whit the results obtained by the case study and the content analysis presented, the project agent interested in the lean application, can use the selected MM to lead a decision in the construction field. Furthermore, the criteria selected to evaluate the MM through a content analysis were chosen based on the researchers' and agents' perception to better express the aspirations of the project under study.

\section{REFERENCES}

Alarcón, L.F., Grillo, A., Freire, J. et al. (2001), “Learning from collaborative benchmarking in the construction industry", in Proceedings of the 9th Annual Conference of the International Group of Lean Construction (IGLC), IGLC, Singapore, available at: http://iglc.net/Papers/Details/129 (accessed 10 May 2019).

Arantes, F.T. (2010), Modelo de Diagnóstico da Maturidade da Construção Enxuta e Estudo de Casos em Empresas da Construção Civil, Trabalho de Conclusão de Curso em Engenharia Civil, Escola de Engenharia de São Carlos, Universidade de São Paulo, São Carlos, SP.

Ballard, G. (2000), The Last Planner System of Production Control, Doctoral Thesis, School of Civil Engineering, University of Birmingham, Birmingham, UK.

Böes, J.S., Rocha, P.H., Cândido, L.F. et al. (2018), “Levantamento de melhores práticas de construtoras cearenses", in Anais do Encontro Nacional de Tecnologia do Ambiente Construído (ENTAC), ANTAC, Foz do Iguaçú, PR.

Brandão, E.L., Pacheco, A.P.G., Wons, L. et al. (2018), “Aplicação do Rapid Lean Construction-Quality Rating Model em obras públicas", in Anais do Encontro Nacional de Tecnologia do Ambiente Construído (ENTAC), ANTAC, Foz do Iguaçú, PR.

Câmara Brasileira da Indústria da Construção - CBIC (2017), Tabela Anual com o Número de Estabelecimentos na Construção Civil por Tamanho no Brasil e Grandes Regiões, CBIC, Belo Horizonte, available at: http://www.cbicdados.com.br/menu/empresas-de-construcao/estabelecimentos-naconstrucao (accessed 10 May 2019). 
Cândido, L.F., Lima, S.H.O. and Barros Neto, J.P. (2016), "Análise de sistemas de medição de desempenho na indústria da construção", Ambiente Construído, Vol. 16, No. 2, pp. 189-208. http://dx.doi.org/10.1590/s1678-86212016000200087.

Carvalho, B.S. (2008), Proposta de uma Ferramenta de Análise e Avaliação das Construtoras em Relação ao Uso da Construção Enxuta, Dissertação de Mestrado em Construção Civil, Universidade Federal do Paraná, Curitiba, PR.

Carvalho, B.S. and Scheer, S. (2017), "Analysis and assessment for lean construction adoption: the DOLC Tool", in Proceedings of the 25th Annual Conference of the International Group of Lean Construction (IGLC), IGLC, Heraklion, Greece, available at: http://iglc.net/Papers/Details/1449 (accessed 10 May 2019).

Crosby, P.B. (1979), Quality is Free: the Art of Making Quality Certain, McGraw-Hill, New York.

Diekmann, J.E., Krewedl, M., Balonick, J. et al. (2004). Application of Lean Manufacturing Principles to Construction, Research Report 191-11, CII/University of Texas, Austin, TX.

Elo, S. and Kyngäs, H. (2008), "The qualitative content analysis process", Journal of Advanced Nursing, Vol. 62, No. 1, pp. 107-15.

Etges, B.M.B.S., Saurin, T.A. and Bulhões, I.R. (2013), "A protocol for assessing the use of lean construction practices", in Proceedings of the 21th Annual Conference of the International Group of Lean Construction (IGLC), IGLC, Fortaleza, CE, available at: http://iglc.net/Papers/Details/896 (accessed 10 May 2019).

Gomes, M.M.B., Cavalcante Filho, J.U.D.P. and Barros Neto, J.P. (2018), "Planejamento estratégico na indústia da construção civil: áreas, temas, técnicas e métodos", in Anais do Encontro Nacional de Tecnologia do Ambiente Construído (ENTAC), ANTAC, Foz do Iguaçú, PR.

Gontijo, D.S.M., Santana, J.C. and Prado, A.A. (2018), Análise dos requisitos para a implementação da filosofia lean green construction em edificações de pequno porte, in Anais do Encontro Nacional de Tecnologia do Ambiente Construído (ENTAC), ANTAC, Foz do Iguaçú, PR.

Hofacker, A., Oliveira, B.F., Gehbauer, F. et al. (2008), "Rapid Lean Construction-quality Rating model (LCR)", in Proceedings of the 16th Annual Conference of the International Group of Lean Construction (IGLC), IGLC, Manchester, UK, available at: http://iglc.net/Papers/Details/573 (accessed 10 May 2019).

Koskela, L. (1992), Application of the New Production Philosophy to Construction. Technical Report No. 72 , CIFE, Stanford University.

Lean Construction Institute - LCl, Ireland Community of Practice (2015), Lean Assessment Tool Baseline for Ireland COP 09022116, LCl, Dublin, Ireland, available at: http://leanconstructionireland.ie/gettingstarted/lean-assessment-tool/ (accessed 10 May 2019).

Lean Construction Institute - LCl (2016), LCI Lean IPD Health and Maturity Assessment Tool 1.0, LCl, Arlington, TX, USA, available at: https://www.leanconstruction.org/learning/tools-and-technologies/ (accessed 10 May 2019).

Li, S., Wu, X., Zhou, Y. et al. (2016), "A study on the evaluation of implementation level of lean construction in two Chinese firms", Renewable \& Sustainable Energy Reviews, Vol. 71, pp. 846-51. http://dx.doi.org/10.1016/j.rser.2016.12.112.

Lorenzon, I.A. (2008), A Medição de Desempenho na Construção Enxuta: Estudos de Caso, Tese de Doutorado em Engenharia de Produção, Universidade Federal de São Carlos, São Carlos, SP.

Lucena, A.F.E. and De Mori, L.M. (2018), "Critical analysis of lean construction measuring tools", Brazilian Journal of Operations \& Production Management, Vol. 15, No. 2, pp. 311-21. http://dx.doi.org/10.14488/BJOPM.2018.v15.n2.a13.

Moon, H.G., Yu, J. and Kim, C. (2007), "Performance indicators based on TFV theory", in Proceedings of the 15th Annual Conference of the International Group of Lean Construction (IGLC), IGLC, East Lansing, Michigan, USA, available at: http://www.iglc.net/Papers/Details/466 (accessed 10 May 2019).

Nesensohn, C. (2014), An Innovative Framework for Assessing Lean Construction Maturity, Doctoral Thesis, Liverpool John Moores University, Liverpool, UK.

Nesensohn, C. (2017), "A lean construction maturity model for organizations", in Proceedings of the 25th Annual Conference of the International Group of Lean Construction (IGLC), IGLC, Heraklion, Greece, available at: http://iglc.net/Papers/Details/1448 (accessed 10 May 2019).

Nesensohn, C., Bryde, D. and Pasquire, C. (2015), "A measurement model for lean construction maturity", in Proceedings of the 23th Annual Conference of the International Group of Lean Construction (IGLC), IGLC, Perth, Australia, available at: http://www.iglc.net/Papers/Details/1166 (accessed 10 May 2019).

Nesensohn, C., Bryde, D., Ochieng, E. et al. (2014), "Maturity and maturity models in lean construction", The Australasian Journal of Construction Economics and Building, Vol. 14, No. 1, pp. 45-59. http://dx.doi.org/10.5130/AJCEB.v14i1.3641. 
Pereira, C.M., Anholon, R. and Batocchio, A. (2017), "Obstacles and difficulties implementing the lean philosophy in Brazilian enterprises", Brazilian Journal of Operations \& Production Management, Vol. 14, No. 1, pp. 218-27. http://dx.doi.org/10.14488/BJOPM.2017.v14.n2.a10.

Pereira, L. and Tortorella, G. (2018), "Identification of the relationships between critical success factors, barriers and practices for lean implementation in a small company", Brazilian Journal of Operations \& Production Management, Vol. 15, No. 2, pp. 231-46. http://dx.doi.org/10.14488/BJOPM.2018.v15.n2.a6.

Pereira, M.D.C. (2012), Avaliação e Análise da Aplicação da Filosofia Lean em Empresas de Construção Civil da Região Metropolitana de Belo Horizonte, Monografia de Especialização em Construção Civil, Universidade Federal de Minas Gerais, Belo Horizonte, MG.

Rentes, A.F. (2009), Modelo Hominiss de Diagnóstico da Maturidade Lean, Hominiss Consulting, São Carlos.

Rodegheri, P.M. and Serra, S.M.B. (2019), "Lean construction and maturity models: five methods applied in the same project", in Proceedings of the 27th Annual Conference of the International Group for Lean Construction (IGLC), IGLC, Dublin, Ireland. https://doi.org/10.24928/2019/0195.

Sainath, Y., Varghese, K. and Raghavan, N. (2018), "Framework for progressive evaluation of Lean Construction Maturity using Multi-Dimensional Matrix", in Proceedings of the 26th Annual Conference of the International Group for Lean Construction (IGLC), (IGLC), Chennai, India. https://doi.org/10.24928/2018/0416.

Salvatierra, J.L., Alarcón, L.F. and Velásquez, X. (2015), “Lean diagnosis for chilean construction industry: towards more sustainable Lean practices and tools", in Proceedings of the 23th Annual Conference of the International Group of Lean Construction (IGLC), IGLC, Perth, Australia, available at: http://www.iglc.net/Papers/Details/1208 (accessed 10 May 2019).

Sarhan, S. and Fox, A. (2013), "Performance measurement in the UK construction industry and its role in supporting the application of lean", The Australasian Journal of Construction Economics and Building, Vol. 13, No. 1, pp. 23-35. http://dx.doi.org/10.5130/ajceb.v13i1.3069.

Serviço Brasileiro de Apoio às Micro e Pequenas Empresas - SEBRAE. (2018), “Critérios de Classificação de Empresas: MEI - ME - EPP", available at: http://www.sebrae-sc.com.br/leis/default.asp?vcdtexto=4154 (accessed 10 May 2019).

Soto Becerra, U.B. (2016), Evaluación de la Madurez de los Principios Lean en Proyectos de Construccion, Tesis de Magister en Ciencias de la Ingeniería, Pontificia Universidad Católica de Chile, Santiago, Chile.

Sousa, D.S.V., Cândido, L.F. and Barros Neto, J.P. (2017), "Medição de desempenho na construção civil: um estudo exploratório com construtoras cearenses", Ambiente Construído, Vol. 18, No. 1, pp. 9-29. http://dx.doi.org/10.1590/s1678-86212018000100207.

Sweis, G.J., Hiyassat, M. and Al-Hroub, F.F. (2016), "Assessing lean conformance by frst-grade contractors in the Jordanian construction industry", Construction Innovation, Vol. 16, No. 4, pp. 446-59. http://dx.doi.org/10.1108/Cl-04-2015-0024.

Tezel, A., Koskela, L. and Aziz, Z. (2017), "Current condition and future directions for lean construction in highways projects: asmall and medium-sized enterprises (SMEs) perspective", International Journal of Project Management, Vol. 36, No. 2, pp. 267-86. http://dx.doi.org/10.1016/j.ijproman.2017.10.004.

The American Institute of Architects (2014), "Integrated project Delivery: an updated working definition", available at: https://aiacalifornia.org/wp-content/uploads/2014/08/AIACA_IPD.pdf (accessed 10 May 2019).

Womack, J. and Jones, D. (1997), "Lean thinking: banish waste and create wealth in your corporation", The Journal of the Operational Research Society, Vol. 48, No. 11, pp. 1144-50. http://dx.doi.org/10.1057/palgrave.jors.2600967.

Yu, I., Kim, K., Jung, Y. et al. (2007), "Comparable performance measurement system for construction companies", Journal of Management Engineering, Vol. 23, No. 3, pp. 131-40. http://dx.doi.org/10.1061/(asce)0742-597x(2007)23:3(131).

Zhou, B. (2016), "Lean principles, practices, and impacts: a study on small and medium-sized enterprises (SMEs)", Annals of Operations Research, Vol. 241, No. 2, pp. 457-74. http://dx.doi.org/10.1007/s10479012-1177-3.

Author contributions: All authors contributed equally to this paper. 